Colloques internationaux

LE FAIT ETHNIQUE

EN IRAN ET EN AFGHANISTAN

Editions du CNRS, Paris, 1988

\title{
Ethnicity and national liberation : the Afghan Hazara between resistance and civil war
}

\author{
by Jan-Heeren GREVEMEYER
}

\section{Introduction}

The war in Afghanistan has been going on now for about seven years and no political solution is in sight. On the contrary : the armed struggle seems to broaden from year to year. This development is last not least due to the changing character of the afghan resistance : Whilst in the beginning principally a general uprising against the socio-political reforms of the central government it took after the russian invasion at the turn of the year 1979/80 soon the quality of a modern guerilla warfare against an "infidel" foreign aggressor. This change of tactics is, however, the reflection of a much wider general social change which has left no aspect of the socio-political and cultural life untouched : Almost unnoticed by western observers a process of modernization from below has developed on the lee side of the war. This process is reflected in the change of military tactics, in the infrastructure of the resistance, in the upcomst of new elites and by the growing importance of ideologies as means for new kinds of social and political relations. But as the success of the resistance hitherto is due to these changes, the same changes have also contributed in creating new internal conflicts, caused by political, religious and ethnic differences transformed into ideologies of nationalism and islamic government.

The history of the Hazaras during the last seven years stands exemplary for these changes and new conflicts. At the same time their history documents the problems, which people, who have been much discriminated against, encounter in the attempt to emancipate itself.

\section{The Hazaras ${ }^{(1)}$}

The area inhibitated by the Hazaras - the Hazarajat - encompasses the whole of Central Afghanistan. It is enclosed by the Hindukush mountain range which runs to the Amu-Darya in the North, into the Iranian lowlands in the West and to the Plain of Beluchestan in the South. The winters are cold and bring much snow, the summers short with little rainfall. This climate severely limits land cultivation : agricultural production is at a subsistence level. The majority of the population manages to survive by growing wheat and barley and keeping sheep and goats. The limited areas of land available for cultivation and its relative infertility compelled many members of this ethnic minority as far back as the 19th century,

(1) The number of studies on the history and socio-political organisation of the Hazaras are limited. The only monographic approaches in European languages originate from Schurmann (1962) and Temirkhanov (1972). Among the articles on the Hazaras one has to mention the contributions of Canfield $(1973 ; 1973 \mathrm{a})$. His studies deal for the main part with the structure of coalitions and loyalties among local Hazara communities. The Afghan historiography treated the history of the Hazaras exclusively in the context of their subjugation and integration into the Afghan state at the end of the 19th century (Ghobar 1346/1967:666-671; Kakar 1971 : 159-179). Among the printed Persian sources, Saraj at tawarikh by Faiz Mohammad Kateb is the most important. Particularly the third volume which deals with the years of 'Abdorrahman's' rule (1890-1901) gives an unique insight into the internal developments in minute detail. Since the author is himself a Hazara, the Hazara War (1889-1893) has been treated moft extensively. 
to leave and go as migratory labourers to Kabul, Kandahar, Herat, British India and Iran or at least to seek temporary employment there throughout the long winter month.

The mongolian features of the Hazaras distinguished them from other ethnic groups in Afghanistan (the Pashtunes, Tajiks and Uzbeks). Traditionally the Hazaras were treated as a nonconformist, hostile, and heretical element. However, the decisive factor influencing their status and hence the way they were treated by neighbouring ethnic groups was that they belong to the Shiite religious sect. In the 19th century this was regarded by the Uzbeks as justification enough to enslave them (Burnes 1834, II : 190); 'Abdorrahman (1880-1901) therefore declared the war against them to be a holy war (Kakar 1971:165); in the 20th century the constitution declared the official state religion of Afghanistan to be the Sunnite faith of Hanafite rite, thereby excluding the Shiite Hazaras as followers of a Yfalse religion" from the Afghan religious community.

The Hazara population was officially given as numbering about one million. This figure was probably manipulated, however. Hazaras assume a population of 4-7 million (Entretien avec Habibollah 1982; Neda-ye khorasan 1983).

The social structures of the Hazaras in the 19th century consisted of a military-political upper-class which was active on a local and regional level, collecting taxes with the aid of paramilitary followers or procuring the means of substantiating their claim to being petty rulers by ruthless economic exploitation. They were legitimized by a class of clerics, who participated in the internal distribution system as owners of endowed land and receivers of ecclesiastical taxes : at the same time they filled administrative posts or had a say in legal affaires. The economy was based mainly on barter (Burnes 1834, I : 177). The upper class lived in fortified castles and were always in rivalry with their neighbours.

The incorporation of the Hazara people into the Afghan state (Ghobar 1346/1967:666-671) at the end of the 19th century was synonymous with the loss of military and political power of the upper classes. The central government, always short of manpower and financial ressources to build up an efficient local administration, thereby were still forced to cooperate with the upper classes of the region. Although they were definitively eliminated from regional positions of political decision making, their hold on the villages became correspondingly stronger. From this base they were in the 20th century able to realign themselves with the official administration. The state needed their knowledge and assistance in collecting taxes and recruiting soldiers. This compromise by the state gave the upper class the chance to establish itself once more politically as local middlemen between the interest of the state on the one hand and those of their dependents on the other. Having changed their base to the village, they were also forced to build up a clientele on the village level.

Bereft of their political-military power, the rural upper classes build up a system based on economic coercion. They did so by making large sections of the rural population dependent through rental tenancy arrangements, investements in the bazar and mechanisms of debt, manipulated through the rental system and bazar interests. They were able to use a good part of that surplus which the state intended to appropriate and that remained in their hands, in an intra-village redistribution for the establishment and maintenance of a new system of clientele. The fact that much of the populace lived in villages and the formation of a modern patron-client system, in which the upper class acted as middlemen and exercised various state functions informally (Schurmann 1962:230 ff.), prevented an organization of the people on a class basis. In the hierarchic system of small collectives, people were bound by personal loyalties.

The Pushtun administrators were only thinly scattered throughout the Hazarajat region and this indeed contributed to the fact, that the Hazarajat was only superficially internally colonised. But this development was accompanied by a consequent policy of marginalisation and of a systematic policy of cultural, economic and political discrimination through the reigning Pushtun elite : The Hazarajat was partitioned for so called administrative purposes; public utilities e.g. schools, clinics, post offices, etc. were either nor established at all or in a very few places and then of an inferior standard; although all Hazaras had to do military service, no Hazara had normally the right to become an officier; it was taboo to narrate the history of the Hazaras. After the Second World War intensive modernisation programmes were implimented but the Hazarajat region did not benefit from any of them. A diffuse but effective oral propaganda campaign defamed the members of this race as second class human beings. 
While the big estate owners who resided in the area became middlemen, the clerical class which was unable to operate outside the region itself because of their Shiite beliefs, had early focussed their attention on foreign countries and were educated in the strongholds of the Shiite faith, in Iran and Iraq. The economic marginalization and the competition from Pushtun merchant nomads in the country were comtributing factors to the permanent internal migration of the poor peasantry to Kabul and a subsequent wave of emigration into neighbouring foreign countries.

The situation of the Hazaras in Kabul (or Iran) is in many ways characteristic of the pariah position of a race : they were underpriveleged politically, socially, economically and culturally and without an autonomous political organ to represent their interests; in the Hazarajat hinterland only communal organisation forms existed which did not allow a fusion outside the villages and dales. In the main they depended for their support on working as porters, labourers, house servants, etc. At the same time, however, some intellectuals began to propagate the nation state idea advocated by the Afghan government whereas the clerics who had studied abroad regarded the Shiite faith as the way to deliverance. The events of $1978 / 79$ ended this pariah existence : in the Hazarajat the oppositional groups were able to remove the administrative authorities and to establish an autonomy; at the same time the ideological elements of a pariah people took shape during the beginning process of re-interpretation of political and religious ideas.

A few month after the April putsch in 1978 a persecution of all opponents began; in addition, a programme of reforms whose main targets were the clergy and the big estate owners was announced with extensive use of propaganda; this had allready led to sporadic revolts in the summer of 1978 . The escalation of the terror against opposition groups and the campaigns to make a revaluation of the U.S.S.R. introduced by the Taraki government confirmed the fears of the mainly clerical Hazara elite in Kabul, that a new kind of discrimination was being put into practice. The first arrests of highranking religious leaders could be revoked. However, as the uprisings in Kunar, Nurestan, Badakhshan and Herat made it apparent that the government would suppress any opposition with all the powers at its disposal and that systematic persecution was beginning in Kabul where several Hazaras were among the victims, the Hazaras decided that it was time to act.

\section{The resistance movement in the Hazarajat}

Western oberservers took little notice of the events which occured in $1978 / 79$ in the Hazarajat. There are, however, some detailed reports published by Hazaras - mainly connected with the activities of the "Shura-ye farhangi-ye mojahedin-e eslami-ye afghanestan" (Quetta) and its intellectual head Mohammad Essa Gharjestani - which enable us to sketch the course of events ${ }^{(2)}$.

The revolt erupted to a great extent spontaneously. As soon as the weather conditions in March/April 1979 permitted the inhabitants of one village to communicate with those in the neighbouring one, several peasants united under the leadership of their village chief and attacked the administration building. For the main part they were armed with a few old rifles, with clubs and knives and had no knowledge of what was happening outside their valley or in Kabul; they overpowered the few

(2) The "Cultural Council of Islamic Freedom Fighters in Afghanistan" has been founded 1983. Since then this council edited - under the intellectual leadership of Mohammad Essa Gharjestani - the first journal by Hazaras for Hazaras in Dari under the title of "Neda-ye khorasan". Until march 1985 eight issues have been edited. Gharjestani personally stands exemplary for the upcomst of new elites in the resistance and for the history of his discriminated people : Born in a small village where he spent his first years of life, he received his primary education from the local molla. After the early death of his father, his mother left for Kabul where she earned her living as a washerwoman. Against the wish of her familly she sent Mohammad Essa to school. His early interest for the Hazara cause led to his dismissal from school. For several years he earned his living as a small shopkeeper. At the same time he was politically activ with other Hazaras. After the putsch of 1978 he went underground; in 1979 he joined the resistance in his homeland the Hazarajat. The internal conflicts between the different resistance groups which emerged after the Soviet invasion caused him to leave for exile in Quetta. Until now he has published several monographes and pamphlets which deal exclusively with the history and society of the Hazaras. Hist most interesting works comprise a detailed description of the integration of the Hazaras into the Afghan state at the end of the 19th century (1984), and a history of the Hazaras up to 1980 (1363/1985). Among his additional publications three pamphlets $(1981 ; 1982 ; 1983)$ are important for an understanding of the events in the Hazarajat since 1978 . 
policemen, drove the official and pro-government representatives of the state (teachers, tax collectors, accountants) out and then went on the next village in order to incite the inhabitants there to emulate their example. As the region was controlled merely by a system of sparsely distributed administrative units, the remoter areas fell into the hands of the local people within a few days for the most part (Gharjestani 1363/1985: 148-191).

From the hinterland the uprising spread to the outskirts of the Hazarajat. On May first of 1979 the population of Bamian - a district center and garrison town - started with their rebellion. The usual picture also here : "The real fight was carried out by simple peasants under the slogans of "freedom for the country' and 'in defence of our Koran and Islam". Within a few days about 4000 people gathered, armed with "knives, swords, sickles, shovels, pickaxes and clubs". Their leaders were secular and religious dignitaries. The government sent helicopters, tanks and troops and was able to push the rebels back. But soon the resistance reorganised and "besieged Bamian resolutely... and cut all lines of communication" (Gharjestani 1360/1981: 53-54).

By the summer 1979 the whole Hazarajat had practically been liberated. Immediately after this success, several dignitaries initiated the unification of the different rebel groups : "Some people from Jaghori came in the course of the year to Waras in order to direct this fusion. To bring this about letters were sent out in all directions and in response, delegates arrived from all districts of the Hazarajat. The Great Council Board began to take shape. This extremely decisive gathering was attended by 1200 delegates from all over the Hazarajat. The result was the founding of a Revolutionary Council for Islamic Unity" (Gharjestani 1982: 27-28).

The titles of the delegates show, that the organisers and members of this council belonged for the overwhelming part to the traditional religious and secular elite of rural Hazarajat. A pamphlet published by the Revolutionary Council in 1982 confirmed this state of affairs. According to the publication the council consisted of four strata : the local clergy, intellectuals and educated moslems, the head of tribes or khans, whitebeards or acknowledged people (Tauhid 1361/1982:2).

Although various splinter parties with their own political aims had allready been in existence in 1979 , this Revolutionary Council was founded as the final authority on civil and military matters with the support of all groups and parties.

The Revolutionary Council was able to establish a civil and military organisation which encompassed the whole Hazarajat region within a short period of time - an indeed unique achievement at that stage of the conflict which in the meantime spread thoughout the country. Following the example of the former partition into administrative units, the Hazarajat was divided into 36 districts which were then combined into 8 military regions according to military considerations. Civil and military organisations were independent of each other : in addition to the governors who were responsible for justice, schools, collection of taxes and cultural affaires, there was a military commander ("Entretien avec Habibollah" 1982). Compulsory military service was generally introduced; if a man who was a migratory worker was unable to perform his one-year military duty, then he had to pay a fine. In addition to the regular troops a militia was formed; every ten families had to sent a volunteer, equip and support him afterwards; $20 \%$ of the harvest yield was to be levied as tax (Roy 1983-84).

A few month after the establishment of the Revolutionary Council, the Soviet army invaded Afghanistan. This introduced another element into the up to now anti-centralistic fight - namely the liberation of the country from a foreign "infidel" oppressor. However, the resultant change in the nature of the armed combat brought far-reaching consequences for the political organisation of the free Hazarajat. Up to that point the Hazara resistance movement - the same applied to various other groups - had been principally an "introverted" revolt. Its main aims were the restauration of the ancient way of life, the abolition of a regime which wanted to interfere with the traditional social conditions in its reform plans and the repulsion of arrogant modernisers. The rebellion had been legitimized from the beginning by religious paroles, but this was really more a vague appeal to the Islamic conscience - it was in fact a peasant uprising under the prevailing patron-client organisation. The administrative system set up by the Revolutionary Council was a reflection of the former just as it members represented the power of the traditional rural upper class. As this revolt began, neither the political leaders nor their followers recognized the social implications of their struggle. Not even after the Soviet troops had 
invaded the country did this attitude change. However, in the course of the now over 5-year long war dramatic changes did occur.

For one thing the army became more professional which resulted in a reorganisation of the command system - the civilian upper class was replaced by qualified military staff. The emmergence of a new elite went hand in hand with the transformation of the uprising into a guerilla warfare. At the same time the appearance of new guiding principles enabled the clergy to corroborate their position as a political elite after this transition from religious to secular power had begun under the Revolutionary Council. The mobilization of the rural populace induced by the new political and military elite broke up the village-centered social system and created a new system of loyalities dependent on party affiliation, ideological creed and technical experience instead of exclusively on family ties and on patron-client relationships.

\section{Cultural emancipation and political re-orientation : the Hazarajat after the Soviet invasion}

The consolidation of the revolution in 1979 under the auspices of a Revolutionary Council had it is true - led to the formation of a common front. But even then organisations such as the "Nasr Party" or the "Harakat-e eslami" existed which did not consider themselves to be merely fortuitous groupings of peasant resistance fighters. The Soviet invasion altered the importance of these parties, however. This development was connected primarily whith the religious alignment of the Shiite Hazaras with Iran.

A majority of the Hazara high clergy studied traditionally in Iran or Iraq. Moreover, the perceptible increase in population after the War combined with the reprisals taken by the central government had as a consequence that thousands of Hazaras went to Iran as guest workers from the $60 \mathrm{~s}$ onwards. Immediately after the Soviet invasion - the revolution in Iran was in the meantime relatively established - those groups which totally supported the Iran or Khomeini's revolutionary model or were at least influenced by this idea drew large crowds. Many of the migratory workers and Hazara theologians who had untill then taught in Iran returned to the Hazarajat and began to organise themselves.

In order to extend its influence over the Shiite Hazaras the Iranian government supported this development in many and varied ways. Just a few month after the Soviet invasion delegates from the Council had been active in Iran and, having obtained military equipment there, had endeavoured to enforce their concepts or organisation and orthodoxy in several places by force of arms on their return. The consequence was the murder of members of the secular upper class, teachers and Sunnite clergy (Gharjestani $1982: 29-32$ ). Nevertheless, it was the Nasr-Party which was officially backed by Iran in $1980 / 81$, because it accepted unconditionally the course adopted by Iran. In the summer of 1982, after a control commission had visited the Hazarajat, Iran decided to form its own party on the pattern of the "Guardians of the Revolution", which quickly gained influence under the name of Sepah (Puig 1984). With backing from Iran and supported by recruits from among the Hazara migrant workers in Iran, Nasr and Sepah bagan systematically to extend their sphere of influence. To achieve their goal of political and ideological leadership they employed military force from the very beginning. First of all, they turned against the Revolutionary Council. They cited ideological and political arguments to justify their actions. Ideologically they advocated an Islamic fundamentalism in the Iranian style. With reference to the Koran, they propagated the vision of an Islamic state and of a moral economy which rejected any form of international demarcation for Moslems whether in the form of a race, a nation or a state. As in Iran, their parole was "neither East nor West" which implies the rejection of all manner of democracies and democratic institutions.

As was the case with many other fundamentalist groups (Hezb-e eslami; Jame'at-e eslami) whose centres are situated in Peshawar/Pakistan, these groups owe their increasing strength principally to the invasion by the Soviets which lent the resistance the aspect of a religious war (Jehad) against the "infidel". In the Hazarajat, however, the ideologisation of the resistance movement was very narrowly connected with a social component - namely the struggle against the big landowners, i.e. the traditional secular upper class (Roy 1983: 40). 
The Iranian influence went deeper, however. Some of the high clergy had already established their own resistance groups in 1979/80 which were active independently of Nasr and Sepah. These clerics had often studied in Iran or Iraq, taught there and occasionally received financial assistance from Qom or Mashhad. Although they normally supported the Iranian revolution, they did reject the Khomeini state model for Afghanistan - mainly for nationalistic reasons : Probably correctly they saw in the theoretical principles and its conception of the state claims to predominance. Fasihi, leader of the "Sazman-e niru-ye afghanestan" and Wusuqi the leader of the "Hezb-e allah" can be named as representative of a Iran-influenced Shiite movement. Both these groups are smaller splinter opposition parties operating on a regional level whose leaders advocate no specific programme of social change. In general, they accept the foundation of an Islamic republic on a federalist basis in which the Hazaras are granted a relative autonomy in political and religious affairs. Such a programme is also identical with that of the Revolutionary Council whose leader, Sayyed 'Ali Beheshti, was also educated in Iran and Iraq and whose publication "Tauhid" has been published since 1980 - generously illustrated with photos of Khomeini and with many articles about the Iranian ideal. The political visions of this group of an ultimately free Afghanistan in which the Hazaras are accorded a regional autonomy and where fundamental human rights are respected and free elections are guaranteed, are for the most part identical with the political ambitions of a third category of resistance groups, whose organisation, leaders und idols reflect mainly the experience of their peasant followers. These third groups draw their strenght less from the propagation of new ideals as from their ability to broaden their interests and to learn from experiences made during the seven years over which the fighting has been going on and in which violent changes have taken place.

The need to seek seasonal work, forced emigration, the mobility resulting from the unusual expansion of the military action radii, the fact that the war has become more professional, the acquaintance with the situation of other guerilla movements and hence also with other ethnic minorities, which previously had been regarded as oppressors and, finally, the campaign of enlightment carried out by their leaders, who have a technical-military legitimization rather than a religious one, are contributing factors to the creation of a new consciousness which completely abolished the former parochial orientation in political matters. Most of the members of the new elite and a good part of their followers are aware that it is not longer a question of their village or valley, but of the society as a whole. Contrary to the fundamentalist groups with their aim of establishing an all-embracing religious authoritarian rule, the other parties or groups are fighting for the most part for the liberation of their country from the Soviet occupation army in order to be able to live without fear of discrimination in a federalistic Afghanistan.

The ideologization of the resistance, the transformation of the clergy to political leaders and the rise of religiously-oriented resistance groups organised at a grassroot level have led to a polarization in the Hazara society which have resulted in severe conflicts.

The resistance groups can be roughly divided into two categories - firstly, those which are regionally orientated and whose programme is the autonomy of the Hazarajat in a future Islamic and federalist state. They either follow the religious ambitions of Iran or stand for an enlightened popular Islam; their political ideas are often strongly influenced by ethnic or communal considerations. On the other hand, there are fundamentalist groups in existance whose idea of Islamic rule can only be realized in a centralized state under an authoritarian leadership. It is above all, the aim of these groups which envisage a religious-authoritarian concept, whose activities have led over the last five years to an effective loss of power for the Revolutionary Council and a conversion of a war of liberation against the Soviet Union to a struggle for the enforcement of their conception of a religious rule.

In 1982 Olivier Roy travelled through the Hazarajat $(1983: 40)$ and could ascertain that "the Hazarajat has in this summer experienced a political crisis without equal. ... A genuine civil war has developed". A number of the former followers of the Revolutionary Council had joined the proKhomeini Nasr-Party and attempted to arrest the remaining members in a putsch (Roy 1983-84). In 1984 the course of the itensified military conflicts had turned in favour of the Nasr and Sepah Parties; two third of the Hazarajat was in their hands ("Retour d'Afghanistan : Le cinquième voyage d'Olivier Roy" 1984). In an Interview which I had in October 1984 in Quetta with representatives of the Nasr-Party, they admitted point-black that there were two wars raging in Afghanistan - one against the Soviet invaders 
and one between the various resistance movements themselves; the latter is almost more important as it must now be decided how the future Afghanistan is to look politically and socially.

\section{Conclusions and perspectives}

The hostilities which have been going on in Afghanistan for nearly seven years have left no aspect of social life untouched: the enormous migration of the people within Afghanistan itself, and the emigration into neighbouring countries, Pakistan and Iran, the collapse of the economy, the dissolution of traditional loyalty structures and the experience made in fighting against an opponent who is technically and organisationally so much superior, have triggered off a learn and consciousness process in the resistance fighters involved and in the sympathetic population. People have been compelled to reflect on former conditions as well as to search for answers to the question of what the future social order in Afghanistan is to be.

The ethnic minority of the Hazaras exemplifies the dramatic changes which have been taking place. Yet while the resistance parties which have been operating from exile - mainly in Pakistan - have attained prominence in the Western media and have been included in the net of international refugee aid and weapon deliveries, there are no reports on the resistance of the traditionally discriminated Hazaras. This is due to a great extent to the religious orientation of the Shiite Hazaras towards Iran, but simultaneously reflects the discrimination which still exists even today. Thanks to the policies of former governments, there are only a few Hazaras who are educated enough to have been able to establish contacts which would enable them to set up and maintain a public relations system comparable to that of the large exile parties; not unexspectedly, these parties are dominated by Pushtunes and Tajiks.

The orientation towards Iran had, and continues to have, far reaching consequences for the economic and political organisation of the resistance movements in the Hazarajat. For one thing, ten thousands of Hazaras are employed in Iran and can thus financially support a significant proportion of the population of the Hazarajat and thus the resistance fighters. Secondly, the new rulers in Iran back the propagation of Khomeini's concepts of an Islamic state and so gain many sympathisers amidst the migratory workers and the clergy who were traditionally educated in Iran. The consequence was an ideologization of the resistance and the establishment of the clergy as political leaders. This process culminated in violent conflicts within the opposition movement which had been unified in 1979 and caused a polarization of the various groups into those which are principally fighting for the foundation of an Islamic Republic according to the Iranian prototype and those which are at war to achieve autonomy for the Hazaras in a federalistic state.

Whatever the political solution will be - one thing is already apparent for all participants today - the fact that both the war against the Soviet occupying forces and the internal disputes are long-lasting, interdependent learning processes which the people of the Hazaras have to endure and survive alone. The final winners are not yet certain. For many the main hope for the future lies in the birth of a new political consciousness. One consequence of this same political consciousness, however, is that the differences between the opposition groups lie in conflicting conceptions of the world and programmes. It appears to be much more difficult to settle these differences than it was to put an end to the traditional conflicts for which there had been arbitration authorities, developed and improved, tried and accepted over centuries. The success of the Hazara uprising will be crucially dependent on whether functioning authorities for the settlement of these new kinds of conflict can be created step-by-step.

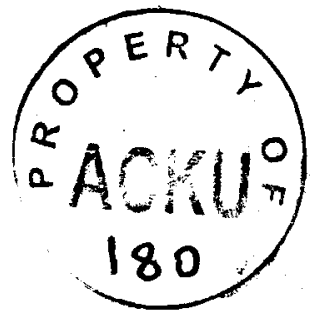

Freie Universität Berlin. 
CANFIELD R.

1973

Faction and Conversion in a Plural Society : Religious Alignements in the Hindu Kush, Ann Arbor, Museum of Anthropology (Anthr. papers, no 50).

1973a

"The Ecology of Rural Ethnic Groups and the Spatial' Bimension of Power", American Anthropologist, 75, p. 1511-1528.

"Entretien avec Habibollah"

1982

Les nouvelles d'Afghanistan, 10, p. 8-10.

GHARJESTANI Mohammad Essa

$1360 / 1981$

1982

1983

"Shekast-e rusha dar hazarehjat", (Quetta).

"Tarikh-e siasi-ye hazarehha-ye afghanestan", (Quetta).

1984

"Peiam-e tarikhi-ye hazarehjat-e afghanestan", (Quetta).

$1363 / 1985$

"Kalamenarha dar afghanestan", (Quetta).

"Rastakhiz-e jang-e afghanestan", (Quetta).

GHOBAR Mir Gholam Mohammad

1346/1967 Afghanistan dar masir-e tarikh, Kabul.

KAKAR Hasan

1971

Afghanistan. A Study in International Political Developments, 1880-1896, Kabul.

KATEB Faiz Mohammad

1331-33q/1912-14 Saraj at-tawarikh (3 vols), Kabul.

Neda-ye khorasan, Quetta (periodical).

PUIG Jean-José

1984

"Voyage en Hazaradjat et au Pandjshir", Les nouvelles d'Afghanistan, 17, p. 15-16.

"Retour d'Afghanistan : le cinquième voyage d'Olivier Roy"

1984

Défis Afghans, 1, p. 8-9.

ROY Olivier 1983

"L'Afghanistan d'est en ouest; compte rendu de voyage 1982", Les nouvelles d'Afghanistan, 12-13, p. 49-51.

1983-84 "La situation au Hazaradjat : la Choura", Les nouvelles d'Afghanistan, 16, p. 10-12.

SCHURMANN H.F. 1962

The Mongols of Afghanistan : An Ethnography of the Moghols and Related Peoples of Afghanistan, - s'Gravenhage, Mouton.

"Tauhid"

1361/1982 Teheran.

TEMIRKHANOV L.

1972

Khazarejtse ocherki po novoi istorii, Moscow. 